\title{
DESCRIPTIVE STUDY OF EXHUMATIONS- A FOUR-YEAR STUDY IN A MEDICAL COLLEGE IN NORTH TAMILNADU- INDIA
}

\author{
Devasahayam Gitanjali ${ }^{1}$
}

${ }_{1}^{1}$ Associate Professor, Department of Forensic Medicine, Government Villupuram Medical College, Villupuram, Tamilnadu, India.

\section{ABSTRACT}

\section{BACKGROUND}

Exhumation is the process of digging out a buried body for post-mortem examination. It is a legitimate process, investigated by a Magistrate's inquest and done in the presence of the Revenue officials, Police and Forensic specialist. Exhumation is done for a number of reasons such as establishment of identity, to know the cause of death, manner of death, to remove suspicions surrounding death and for medical insurance problems. The number of exhumations is on the rise, since there is increased awareness of people's rights among the public. When compared to conventional autopsy which is taken up soon after the death, exhumation usually done after a period of time poses many difficulties.

\section{MATERIALS AND METHODS}

The present study was a descriptive study aimed at analysing the exhumations with regard to age, sex, marital status, religion, place of burial, time interval between burial and post-mortem, reason for exhumation, distance travelled between the post-mortem centre and site of exhumation, post mortem changes noted and cause of death.

\section{RESULTS}

A total of 3100 autopsies were done in the Department of Forensic Medicine, Government Villupuram Medical College, North Tamilnadu in the period of 4 years (2012 - 2015). There were a total of 19 exhumations and amongst them were 12 males (63.16\%) and 7 females (36.84\%). Their age ranged from 13 years to 70 years. Most of them were Hindus and married. Time interval between burial and exhumation was between 1 and 3 months in most of the cases and the longest time interval was 1 year, 5 months and 19 days in 1 case. According to the present study, the cause of death on exhumation could be clearly determined in 8 cases (42.10\%). In other 11 cases (57.89\%), no definite opinion was possible. Putrefaction, mummification, adipocere formation and skeletonization (Incomplete) were noticed. Different types of decomposition were noticed in the same body.

\section{CONCLUSION}

In India the burial practices like the place, the depth and the manner of wrapping the body, the religious practices, the season of the year and the post-mortem interval play a major role in the possible outcome at exhumation.

\section{KEY WORDS}

Autopsy, Exhumation, Decomposition, Cause of Death.

HOW TO CITE THIS ARTICLE: Gitanjali D. Descriptive study of exhumations- a four-year study in a medical college in north Tamilnadu- India. J. Evolution Med. Dent. Sci. 2018;7(23):2757-2760, DOI: 10.14260/jemds/2018/623

\section{BACKGROUND}

The term exhumation means, ex- Out of, Humus- Ground, Exhume- To bring it outside after a period of burial. ${ }^{1}$ It is a medico-legal digging out of a buried body. The buried dead body is brought out and autopsy done in the same spot or the remains shifted to the postmortem centre for autopsy.

Exhumations are taken up for many reasons. These may be to find out the actual cause of death and the manner of death when there are a number of allegations due to jealousy, breach of trust, political enmity etc.[1-4]

During the recent times, there is increased awareness of the general public about individual rights. The Law of the land protects the body buried in 'consecrated' ground, like a cemetery or burial place and permission must be sought from the competent authorities before any exhumation can be

'Financial or Other Competing Interest': None.

Submission 23-04-2018, Peer Review 18-05-2018,

Acceptance 25-05-2018, Published 04-06-2018.

Corresponding Author:

Dr. Devasahayam Gitanjali,

Department of Forensic Medicine,

Government Villupuram Medical College,

Villupuram-605601, Tamilnadu, India.

E-mail: gitanjalidrfm@gmail.com

DOI: $10.14260 /$ jemds $/ 2018 / 623$ carried out. All the exhumed cases are dealt with under section 176 Cr. P. C. Executive Magistrate conducts an inquest. Revenue officials like Sub-Collector, Executive Magistrate, Revenue Divisional Officers or Tahsildars are designated for this purpose. These officials along with the Police of the said jurisdiction carry out the task with the help of the Forensic team from the designated autopsy centre.

Presence of certain poisons and osteological evidence in the form of fractures may be preserved for many years. Morphological evidence depends on the method of burial, time interval between burial and exhumation and other factors influencing decomposition.[5] Exhumation is infrequently done in India because the bodies are disposed off by burning to ashes by most of the communities except few, where the dead are buried.[6] According to the French philosopher and death expert Philippe Aries, Necrophiliacs are said to disinter dead bodies for sexual purposes.

\section{Aims and Objectives of Present Study \\ To make a Comprehensive Descriptive Study of the Exhumation Deaths with Regard to-}

1. Age, marital status, religion of the deceased and cause of death. 
2. Site of exhumation, distance between autopsy centre and site of exhumation and time interval between burial and exhumation.

\section{MATERIALS AND METHODS}

This is a descriptive study, the Autopsy following exhumation was done on a total of 19 cases by a team of doctors from the Department of Forensic Medicine, Government Villupuram Medical College, Tamilnadu in this period of four years 2012 2015.

After bringing out the body from the burial site and after confirming its identity by near relatives, then only the autopsy procedure was initiated.

Data was collected from the papers submitted by the Magistrate- Inquest paper, Revenue officials- details of the deceased, details of the burial site etc., Police- History of the case, particulars of the investigation, statements of the family members etc.

Among the 19 cases, in 1 case autopsy was already performed and exhumation was done on request of relatives and on Magistrate's order. In the rest of the 18 cases, bodies have been secretly buried without informing the Police and without proper investigation.

In all the 19 cases autopsy was done at the site of exhumation itself by a team of 2 doctors, headed by the author from the Department of Forensic Medicine, Government Villupuram Medical College. The inquesting Magistrate and the Police officials of that particular station were present.

The samples collected were sent to forensic laboratory for analysis.

\section{RESULTS}

There were a total of 3100 autopsies conducted in our centre in the period of 4 years from 2012 to 2015, and out of which 19 autopsies were following exhumation.

Amongst 19 exhumations, 12 were males (63.16\%) and 7 were females (36.84\%).

Their age ranged from 13 years to 70 years. A maximum no. of 9 cases were in the age group of 21 - 30 years and the mean age was 31.57 years (Chart 1 ).

Among the 19 persons 6 males were married, 6 were unmarried, 5 females were married and 2 were unmarried (Chart 2).

As far as religion was concerned 14 were Hindus, 4 were Christians and 1 was a Muslim.

Among the 19 individuals 8 Hindus were buried in their burial place, 3 Christians in their cemeteries, 1 Muslim in their cemetery, 3 persons were buried in open places and one each in the house, lake, forest and seashore (Chart 3).

Time interval between burial and exhumation was between 1 and 3 months in a maximum number of 7 cases. In 5 cases, it was between 1 and 2 weeks. The longest time interval between burial and exhumation was 1 year, 5 months and 19 days in 1 case (Chart 4). The cause of death on exhumation could be clearly determined in 8 cases $(42.10 \%)$.

Death due to chest Injuries- 3 , head injuries- 2, suicidal hanging- 2 and electrocution- 1 . In the 11 other cases (57.89\%) no definite opinion was possible, because of burial practices and decomposition due to prolonged time interval between burial and exhumation (Chart 5).

The distance from the medical college to the various exhumation sites ranged from 10 kilometers to 150 kilometers. Majority of them were between 75 to 100 kilometers in 13 cases (68.43) and the longest distance was 145 kilometers.

When the reason for exhumations of these 19 cases were analysed- the relatives of deceased believed that there was some foul play in the death of the deceased in 11 cases. In 1 case where autopsy was already done, the relatives alleged that it was not conducted properly by the doctor. In the other 7 cases, 4 were suspected murders. In 2 cases the bodies were disposed off after death following electrocution and in 1 case after an accident.

The depth of the burial place varied from 1 foot to 7 feet.

Putrefaction was noted in 6 bodies, mummification in 2 bodies, adipocere formation in 3 cases and skeletonization (Incomplete) in 6 corpses. Different types of decomposition were noticed in the same body.

There were problems in conducting exhumation, because of objection due to religious beliefs in Christians.

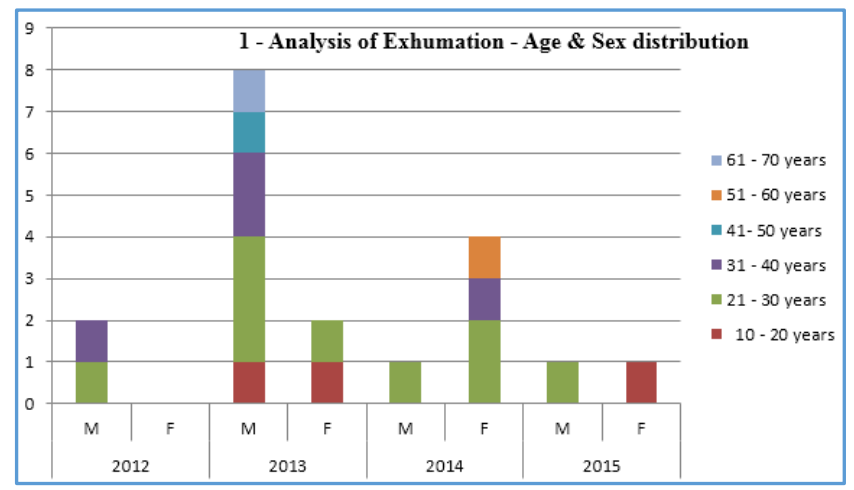

2 - Analysis with respect to Marital Status and Gender
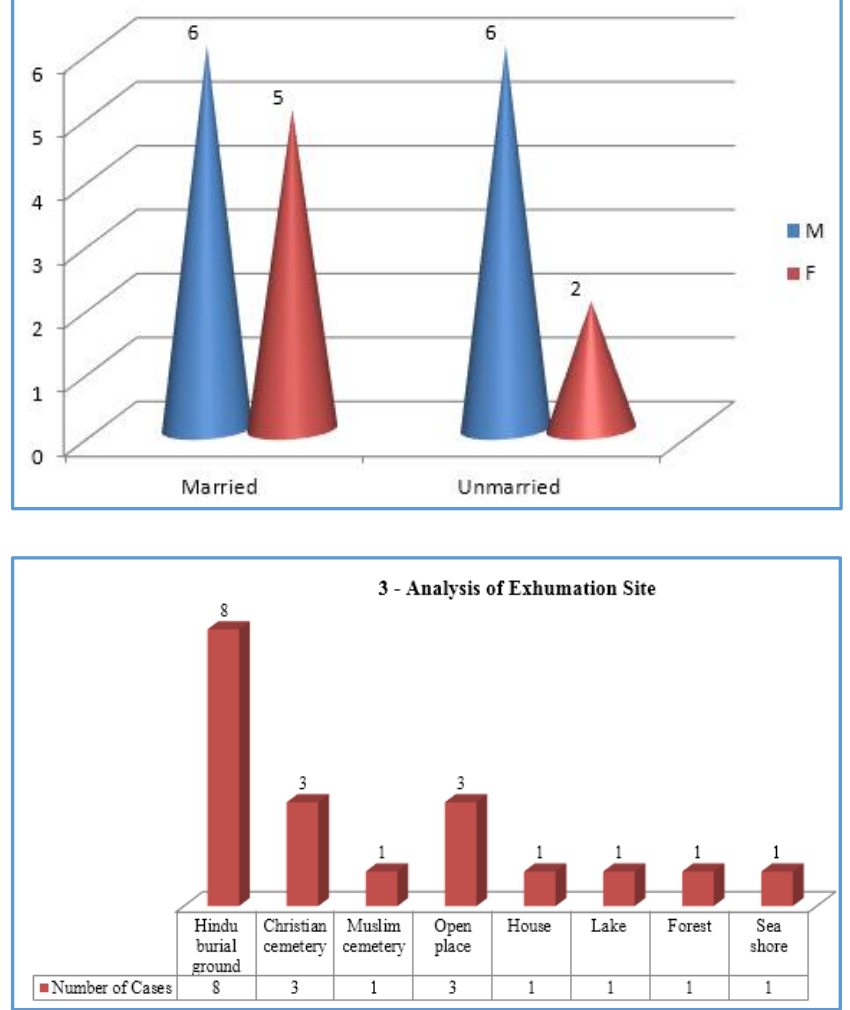

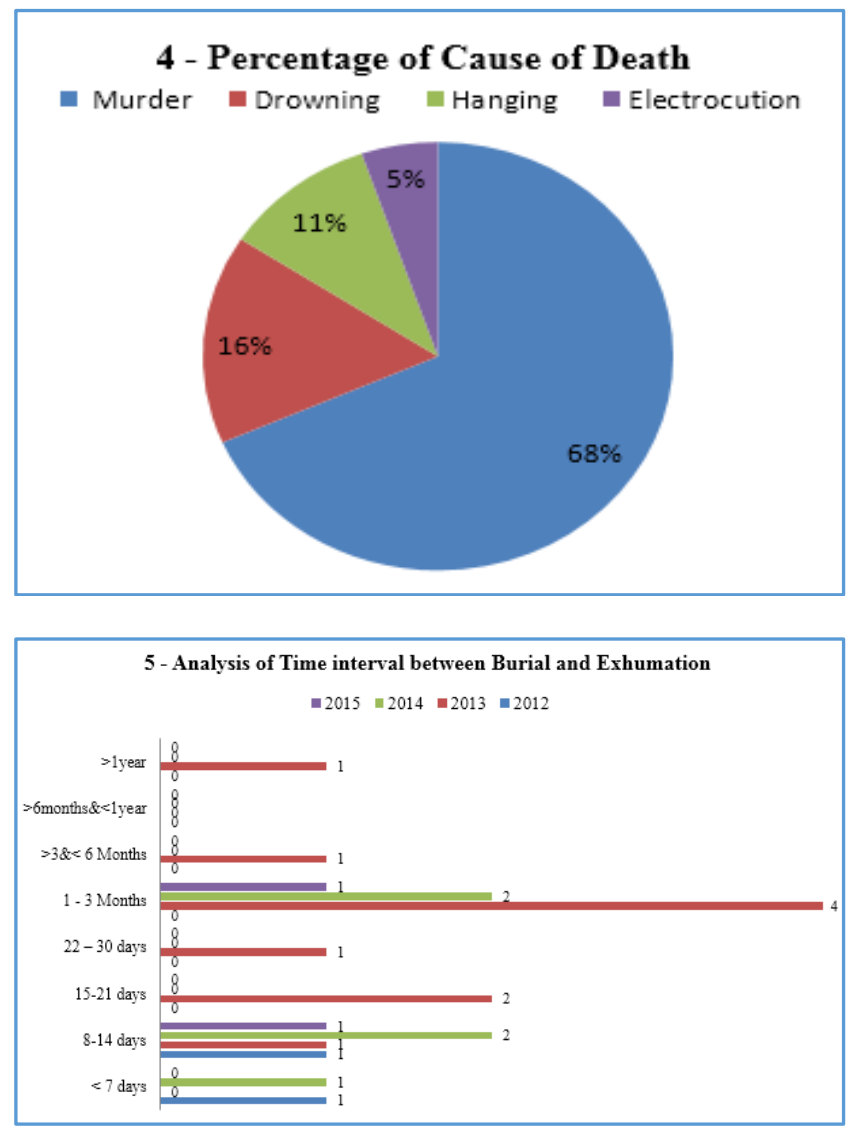

\section{DISCUSSION}

Every exhumation involves extensive preparation on the part of all the three- Forensic team, Revenue officials and the Police. Our autopsy centre, caters to the need of 2 districts with over 100 police stations.

The number of exhumations carried out in India is not sufficient to do a comprehensive study of the gross findings and microscopic changes occurring in the body after burial.[6]

Before an exhumation, the question of its usefulness arises, because there is constant apprehension for the Forensic pathologist whether positive findingsmorphological or toxicological findings can be detected after increased time interval.[7]

In our study, males outnumbered females and most of them were in the age group of 21 - 30 years and the mean age was 31.57 years.

Most of them were married and belonged to the majority Hindu religion.

The reason for exhumations was suspected foul play by the relatives in the death of the deceased in most cases.

The depth of the burial place varied from 1 foot in a case of burial in the forest (Shallow burial place) to 7 feet in the case of the body being buried in a Christian cemetery.

Except where the body was buried near a lake which was damp in all other cases the soil of the burial place was dry, making it very difficult for the workers who helped in disinterring the body.

The bodies buried in the Christian cemeteries were buried in wooden boxes, wrapped in white cotton cloth which has become discoloured. In other cases the deceased were buried in their own clothes. The body of the school boy was buried in his school uniform itself.

The distance travelled by the Forensic team to the exhumation site varied from few to several kilometres.
The season of the year, when exhumations are taken up is a very important factor.

In the present study, the cause of death at exhumation was clearly determined in 8 cases $(42.10 \%)$ However, other series have variable rates. In a study by Grellner et al (1997),[7] the cause of death could be provided in $78 \%$ of cases and in 66.6\% with Karger et al (2004).[8]

One to 3 months was the time interval between burial and exhumation in majority of cases and the longest time was 1 year, 5 months and 19 days.

Compared to an autopsy performed immediately after death, second autopsy on exhumed body brings additional problems. Here, the interpretation of the findings is difficult due to various artefacts of burial and exhumation and the alterations resulted from the first autopsy.

In the present series, we are able to provide the cause of death in one case of second autopsy (category I) that helped to end the suspicions of the relatives.

On the whole (category I + II), in $42.10 \%$ we were able to furnish cause of death with mean post-mortem interval of 62.15 days. This figure is due to the long time delay between death and exhumation and this could drop further with longer post-mortem interval.

In the present study Putrefaction, Mummification, Adipocere formation and Skeletonization (Incomplete) were noted. Different types of decomposition were noticed in the same body.

In India the burial practices like the place, the depth and the manner of wrapping the body, the religious practices, the season of the year and the post-mortem interval play a major role in the possible outcome at exhumation.

In spite of the above constraints, the cause of death could still be ascertained in a good number of cases.

With certain constraints the present study emphasizes the importance of exhumations, even after considerable postmortem intervals.

\section{CONCLUSION}

According to the present study, the cause of death, on exhumation, could be clearly determined only in $42.10 \%$ of the cases and in other $57.89 \%$ cases, no definite opinion was possible. Putrefaction, Mummification, Adipocere formation and Skeletonization (Incomplete) were noticed. Different types of decomposition were noticed in the same body.

So, in India the burial practices like the place, the depth and the manner of wrapping the body, the religious practices the season of the year and the post-mortem interval play a major role in the possible outcome at exhumation.

\section{REFERENCES}

[1] Aggrawal A. Exhumation - medical and legal aspects. Anil Aggrawal's Internet Journal of Forensic Medicine and Toxicology 2001;2(2). http://www.geradts.com/anil/ij

[2] Duff EJ, Johnson JS. Some social and forensic aspects of exhumation and reinterment of industrial revolution remains. BMJ 1974;1(5907):563-7.

[3] Calacal GC, Delfin FC, Tan MM, et al. Identification of exhumed remains of fire tragedy victims using conventional methods and autosomal/Y-chromosomal short tandem repeat DNA profiling. Am J Forensic Med Pathol 2005;26(3):285-91. 


\section{Jemds.com}

[4] Salgado MS, De Alwis LB, Perera N. Identification from skeletal remains. Forensic Sci Int 1988;36(1-2):73-80.

[5] Verhoff MA, Ulm K, Kreutz K, et al. Exhumation as a matter of fact. Anil Aggrawal's Internet Journel of Forensic Medicine and Toxicology 2007;8(1). http://www.geradts.com/anil/ij

[6] Ray SK, Gupta SBK. Exhumation. J Indian Med Assoc 1966;46:193-7.

\section{Original Research Article}

[7] Grellner W, Glenewinkel F. Exhumations: synopsis of morphological and toxicological findings in relation to the postmortem interval. Survey on a 20-year period and review of the literature. Forensic Sci Int 1997;90(1-2):139-59.

[8] Karger B, de la Grandmaison LG, Bajanowski T, et al. Analysis of 155 consecutive forensic exhumations with emphasis on undetected homicides. Int J Legal Med 2004;118(2):90-4. 